The Yard of Wit 



\title{
The Yard of Wit
}

Male Creativity and Sexuality,

1650-1750

\author{
RAYMOND STEPHANSON
}

$\overline{\text { PENN }}$

University of Pennsylvania Press

Philadelphia 
Copyright (C) 2004 University of Pennsylvania Press

All rights reserved

Printed in the United States of America on acid-free paper

$\begin{array}{llllllllll}10 & 9 & 8 & 7 & 6 & 5 & 4 & 3 & 2 & 1\end{array}$

Published by

University of Pennsylvania Press

Philadelphia, Pennsylvania 19104-4011

Library of Congress Cataloging-in-Publication Data

Stephanson, Raymond.

The yard of wit : male creativity and sexuality, 1650-1750/Raymond Stephanson. p. $\mathrm{cm}$.

ISBN 0-8122-3758-7 (cloth : alk. paper)

Includes bibliographical references ( $p$. ) and index.

1. Pope, Alexander, 1688-1744-Authorship. 2. English literature-18th century-History and criticism. 3. Masculinity in literature. 4. English literature-Male authors-History and criticism. 5. English literature-Early modern, 1500-1700-History and criticism. 6. Authors, English-Early modern, 1500-1700-Psychology. 7. Authors, English-18th century-Psychology. 8. Male authors, English-Sexual behavior. 9. Male authors, English-Psychology. 10. Creation (Literary, artistic, etc.). 11. Body, Human, in literature. 12. Generative organs, Male. 13. Men in literature. 14. Sex in literature. 15. Creative ability. I. Title.

PR448.M37 S74 2004

$820.9^{\prime} 353-d c 22$

2003055566 
For Lesley, Stella, and Eric 
